\title{
Effect of long term treatment with oxitropium bromide on airway secretion in chronic bronchitis and diffuse panbronchiolitis
}

\author{
J Tamaoki, A Chiyotani, E Tagaya, N Sakai, K Konno
}

\begin{abstract}
Background - Anticholinergic bronchodilator drugs improve lung function in chronic bronchitis but less is known of their effects on the volume and physical properties of sputum in conditions associated with excessive airway secretions. This study examines the effects of the regular use of oxitropium bromide in such patients.
\end{abstract}

Methods - The study was conducted in a parallel, double blind, placebo controlled fashion. Patients were divided into two groups: the first group $(n=17)$ received oxitropium bromide from a metered dose inhaler (two puffs three times daily; $100 \mu \mathrm{g} / \mathrm{puff}$ ) for eight weeks, and the second group $(n=16)$ received placebo. Lung function was measured as forced expiratory volume in one second $\left(F E V_{1}\right)$ and vital capacity. In evaluating airway secretion, daily amount of expectorated sputum, percentage solid composition, viscoelastic properties including elastic modulus and dynamic viscosity, and sputum microbiology were determined.

Results - Oxitropium bromide increased FEV and decreased the mean (SE) sputum production from $61(4)$ to $42(3) \mathrm{g} /$ day after treatment, whereas placebo had no effect. Bacterial density and sputum flora were unchanged, but solid composition and elastic modulus increased from $2 \cdot 52(0 \cdot 43) \%$ to $3 \cdot 12(0 \cdot 34) \%$, and 68(12) dyne/ $\mathrm{cm}^{2}$, respectively, in the group taking oxitropium bromide.

Conclusions - Regular treatment with oxitropium bromide not only improves airflow limitation but also reduces sputum production, probably through the inhibition of both mucus secretion and water transport, the latter component being predominant.

(Thorax 1994;49:545-548)

Parasympathetic cholinergic receptor antagonists have proved to be useful bronchodilators in the long term management of chronic airway obstruction ${ }^{1}$ and are now widely used in the treatment of chronic obstructive pulmonary disease (COPD) and asthma. Oxitropium bromide is an anticholinergic quaternary ammonium compound and has been reported to be as effective as ipratropium bromide in reducing bronchoconstriction in chronic bronchitis $^{2}$ and asthma. ${ }^{3}$
In addition to the severity of airflow limitation, chronic sputum production is significantly associated with increased mortality of patients with COPD. ${ }^{4}$ As animal experiments have shown that cholinergic tone plays a putative role in mucus secretion from submucosal glands and goblet cells, ${ }^{56}$ and also in water secretion across airway epithelium, ${ }^{7}$ anticholinergic agents may reduce sputum production. We wished to investigate whether regular treatment with oxitropium bromide administered from a metered dose inhaler would influence airway secretion. A placebo controlled trial was performed in a group of patients with either chronic bronchitis or diffuse panbronchiolitis. Diffuse panbronchiolitis is a recently described clinicopathological entity found in Japanese, Chinese, and Korean populations ${ }^{89}$ which is characterised by severe chronic airflow limitations and excessive sputum production accompanied by persistent sinopulmonary infection, respiratory bronchiolitis, and peribronchiolitis.

\section{Methods}

PATIENTS

Thirty three patients (23 men), aged 41-83 years with chronic bronchitis or diffuse panbronchiolitis who had been continuously expectorating more than $30 \mathrm{~g}$ of sputum/day for at least two weeks before the study were selected after obtaining their consent. All patients with chronic bronchitis conformed to the World Health Organisation definition of the disease ${ }^{10}$ and were or had been heavy smokers. The diagnosis of diffuse panbronchiolitis was established by transbronchial lung biopsy. ${ }^{8} 9$ None of the patients had received treatment with antibiotics, mucolytic agents, corticosteroids, or anticholinergic agents during the previous 14 days. In 10 patients (four with chronic bronchitis and six with diffuse panbronchiolitis) the expectorated secretions contained Pseudomonas aeruginosa, eight had Haemophilus influenzae, and two had Staphylococcus aureus, but there was no evidence of consolidation on the chest radiograph.

\section{STUDY DESIGN}

The study was designed in a parallel, double blind, placebo controlled fashion with a two week run-in period. A doctor not involved in the disease follow up or data analysis was assigned the task of dividing the patients into two groups matched for clinical diagnosis and 
sputum production (table 1). Patients continued their usual therapy including oral and inhaled $\beta_{2}$ adrenergic agonists and oral theophylline preparations. Oral $\beta_{2}$ adrenergic agonist and theophylline were administered twice daily and inhaled $\beta_{2}$ adrenergic agonist was used on an as needed basis. In the first group (oxitropium, $\mathrm{n}=17$ ) patients received oxitropium bromide from metered dose inhalers without a spacer (two puffs three times daily; $100 \mu \mathrm{g} /$ puff, Boehringer Ingelheim, Tokyo, Japan) for eight weeks. In the second group (placebo, $\mathrm{n}=16$ ) patients received an identical placebo by the same route and the same schedule. All patients were instructed to inhale the medication in a recommended manner. ${ }^{11}$ Compliance was assessed by weighing the metered dose inhalers at the start and end of the trial and was expressed as a percentage of the mean weight loss from eight metered dose inhalers tested in our laboratory.

\section{CLINICAL ASSESSMENTS}

To assess the effects on pulmonary function, forced expiratory volume in one second $\left(F_{1} V_{1}\right)$ and vital capacity (VC) were measured before and after the eight week study period using a Benedict-Roth spirometer (model OSP-111, Chest Co, Tokyo, Japan) and the values standardised to those predicted for the patient's age and height. The time lag between the last administration of oxitropium and spirometry was 3-4 hours. There were no differences in the severity of airflow limitation between the patients with chronic bronchitis and those with diffuse panbronchiolitis.

\section{SPUTUM ANALYSIS}

To assess the quantity of sputum production patients were given preweighed, covered plastic cups and asked to collect all sputum expectorated during a 24 hour period for eight weeks. They were also asked to swallow saliva immediately before expectoration of sputum to minimise contamination. The collected sputum samples were transported to the laboratory every eight hours and, after determining the wet weight, a sample of the sputum was

Table 1 Demographic characteristics of patients

\begin{tabular}{lll}
\hline & $\begin{array}{l}\text { Oxitropium } \\
\text { group } \\
(n=17)\end{array}$ & $\begin{array}{l}\text { Placebo } \\
\text { group } \\
(n=16)\end{array}$ \\
\hline $\begin{array}{lll}\text { Age (years) } \\
\text { Range }\end{array}$ & $\begin{array}{l}69(5) \\
41-83\end{array}$ & $\begin{array}{l}59(4) \\
43-79\end{array}$ \\
$\begin{array}{l}\text { Sex (n) } \\
\text { Male }\end{array}$ & & \\
$\quad$ Female & 12 & 11 \\
Smoking (n) & 5 & 5 \\
Smoker & & \\
Ex-smoker & 5 & 4 \\
Non-smoker & 9 & 10 \\
Diagnosis & 3 & 2 \\
CB & & \\
DPB & 13 & 12 \\
Other therapy (n) & 4 & 4 \\
Oral $\beta_{2}$ agonists & & \\
Inhaled $\beta_{2}$ agonists & 7 & 5 \\
Oral theophylline & 8 & 9 \\
\hline
\end{tabular}

$\mathrm{CB}=$ chronic bronchitis; $\mathrm{DPB}=$ diffuse panbronchiolitis. dried in a microwave oven ( $500 \mathrm{~W}$ for 30 minutes) and reweighed. The percentage solid composition was then calculated from the ratio of wet to dry weight. ${ }^{12}$

To evaluate changes in rheological properties of the sputum, viscoelasticity - that is, elastic modulus $\left(G^{\prime}\right)$ and dynamic viscosity $\left(\eta^{\prime}\right)$ - were measured before and after the eight week study period. Whenever possible four specimens from each sputum sample produced between 08.00 and 12.00 hours were tested and the results were expressed as the mean. We performed a microrheometric method of Lutz and associates ${ }^{13}$ in that a magnetically oscillated steel microsphere suspended in a drop of mucus was used as a mechanical probe, and the oscillation amplitude of a $100-200 \mu \mathrm{m}$ iron sphere driven by sinusoidal magnetic forces was recorded. The measurements were made at a frequency of $10 \mathrm{~Hz}$, chosen because this approximates to human tracheal ciliary beat frequency. ${ }^{14}$

To assess bacterial density in the sputum, $500 \mathrm{mg}$ sputum aliquots were diluted 1:1 in water, vortexed to achieve a uniform suspension, and further diluted in water in serial 10-fold increments. These samples were spread on sheep blood agar, MacConkey agar, colistin/nalidixic acid/sheep blood agar, and Haemophilus isolation agar, and colony counts on the plates were made to calculate $\log _{10}$ colony forming units (CFU)/g sputum. ${ }^{15}$ Pseudomonas aeruginosa was identified as Gram negative, non-lactose fermenting colonies, and other organisms were identified by conventional techniques. The bacterial colonisation was more pronounced in patients with diffuse panbronchiolitis than those with chronic bronchitis, but it was not significantly different between the oxitropium and placebo groups.

\section{STATISTICAL ANALYSES}

All statistical analyses were performed by the Kruskal-Wallis one way analysis of variance, and a value of less than 0.05 was considered significant.

\section{Results}

During the inhalation trials three patients taking oxitropium complained of an unpleasant taste and one of dryness in the mouth, but other side effects were not observed. All patients completed the study protocol, with a compliance of medication of $98(5) \%$ and $101(6) \%$ for placebo and oxitropium, respectively, over the eight week treatment period.

There were no differences in the administered dose of each bronchodilator agent including oral and inhaled $\beta_{2}$ adrenergic agonists and oral theophylline between and during the trials in either group. In the placebo group no significant change in $F E V_{1}$ or VC was observed after eight weeks of inhalation (table 2 ). In the oxitropium group $F E V_{1}$ increased from $67.6(4.0) \%$ to $75.3(3.2) \% \quad(p<0.05$, $\mathrm{n}=17$ ) but VC remained unchanged. Although this increase was small, an improvement was seen in 15 of the 17 patients. 
Table 2 Mean (SE) values before and after eight weeks of treatment with oxitropium bromide or placebo

\begin{tabular}{|c|c|c|c|c|c|c|}
\hline & \multicolumn{3}{|c|}{ Oxitropium group $(n=17)$} & \multicolumn{3}{|c|}{ Placebo group $(n=16)$} \\
\hline & Before & After & Difference & Before & After & Difference \\
\hline $\begin{array}{l}\text { Sputum } \\
\text { Wet weight (g/day) } \\
\text { SC }(\%) \\
\mathrm{G}^{\prime}\left(\text { dyne } / \mathrm{cm}^{2}\right) \\
\eta^{\prime}(\text { poise }) \\
\text { Log }_{10} \text { CFU bacteria/g } \\
\text { FEV }(\% \text { pred }) \\
\text { VC (\% pred) }\end{array}$ & $\begin{array}{l}61(4) \\
2 \cdot 52(0 \cdot 43) \\
68(12) \\
32(14) \\
4 \cdot 7(0 \cdot 7) \\
67 \cdot 6(4 \cdot 0) \\
84 \cdot 4(3 \cdot 5)\end{array}$ & $\begin{array}{l}42(3) \\
3 \cdot 12(0 \cdot 34) \\
97(20) \\
40(22) \\
3 \cdot 9(1 \cdot 0) \\
75 \cdot 3(3 \cdot 2) \\
84 \cdot 7(2 \cdot 5)\end{array}$ & $\begin{array}{l}\mathrm{p}<0.001 \\
\mathrm{p}<0.05 \\
\mathrm{p}<0.05 \\
\text { NS } \\
\text { NS } \\
\mathrm{p}<0.05 \\
\text { NS }\end{array}$ & $\begin{array}{l}60(3) \\
2 \cdot 43(0 \cdot 72) \\
57(23) \\
38(17) \\
3 \cdot 7(0 \cdot 8) \\
71 \cdot 3(2 \cdot 8) \\
81 \cdot 0(3 \cdot 3)\end{array}$ & $\begin{array}{l}57(3) \\
2 \cdot 37(0 \cdot 60) \\
63(18) \\
33(21) \\
3 \cdot 2(0 \cdot 6) \\
73 \cdot 7(4 \cdot 5) \\
83 \cdot 1(2 \cdot 8)\end{array}$ & $\begin{array}{l}\text { NS } \\
\text { NS } \\
\text { NS } \\
\text { NS } \\
\text { NS } \\
\text { NS } \\
\text { NS }\end{array}$ \\
\hline
\end{tabular}

$\mathrm{SC}=$ solid composition; $\mathrm{G}^{\prime}=$ elastic modulus; $\eta^{\prime}=$ dynamic viscosity; $\mathrm{CFU}=$ colony forming units; NS= not significant.

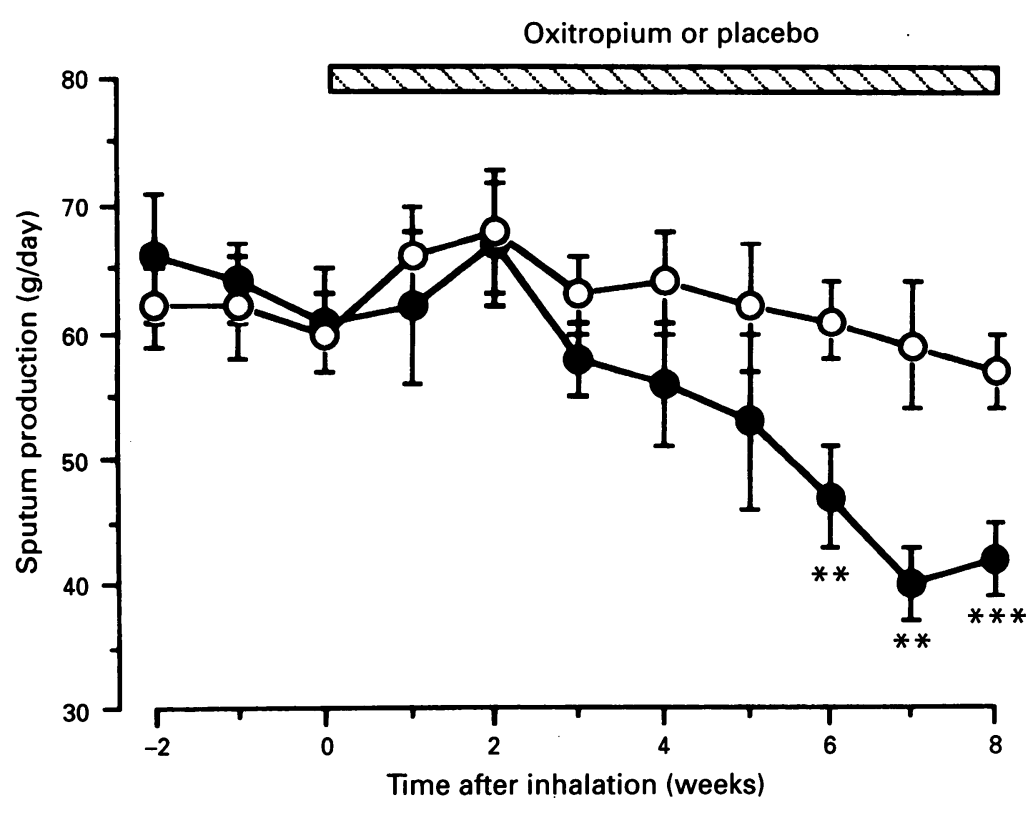

Figure 1 Time course of the amount of daily production of sputum in patients with chronic bronchitis and diffuse panbronchiolitis. Inhalation of oxitropium bromide (or placebo ( $\bigcirc)$ was conducted for eight weeks after a two-week observation period. Bar lines indicate $1 S E$ ( $n=17$ for oxitropium group and $n=16$ for placebo group). ${ }^{* *} p<0.01,{ }^{* * *} p<0.001$, significantly different from values for placebo.



Figure 2 Individual values for daily sputum production before ( 0 week), during (4 week) and after ( 8 weeks) the treatment with oxitropium bromide or placebo in patients with chronic bronchitis (-) and diffuse panbronchiolitis (---).
As shown in fig 1 , in both patients taking oxitropium and those taking placebo the volume of sputum on the day immediately before trial (day 0) did not differ from that recorded during the previous two week observation period. During the eight week trial period the amount of daily sputum production in the placebo group changed by less than $11 \mathrm{~g} /$ day. In contrast, inhalation of oxitropium gradually decreased sputum production, and this became significant after six weeks and remained so. The sputum decreased from the baseline value of $61(4) \mathrm{g} /$ day to $42(3) \mathrm{g} /$ day after eight weeks $(\mathrm{p}<0.001, \mathrm{n}=17$ ) (fig 2). Patients with diffuse panbronchiolitis produced greater quantities of sputum than did those with chronic bronchitis, but the efficacy of oxitropium was similar in the two diseases.

Inhalation of oxitropium for eight weeks increased the percentage solid composition of the sputum from $2.52(0.43) \%$ to $3.12(0.34) \%$ $(\mathrm{p}<0.05, \mathrm{n}=17)$, whereas placebo had no effect (table 2). In the oxitropium group the elasticity $\left(G^{\prime}\right)$ of the sputum increased from 68 (12) dyne $/ \mathrm{cm}^{2}$ on day 0 to $97(20)$ dyne $/ \mathrm{cm}^{2}$ after eight weeks $(\mathrm{p}<0.05, \mathrm{n}=17)$. The dynamic viscosity $\left(\eta^{\prime}\right)$ also tended to increase from 32 (14) to 40 (22) poise, but this was not significant. In both groups there was no change in the total bacterial $\mathrm{CFU} / \mathrm{g}$ sputum during the inhalation trials, nor any difference in bacterial flora in the sputum.

\section{Discussion}

This study demonstrates that regular inhalation of oxitropium bromide not only improved airflow limitation but also decreased the amount of sputum expectorated in patients with either chronic bronchitis or diffuse panbronchiolitis. Although salivary contamination cannot be excluded, the patients were instructed to swallow saliva before expectoration and only one patient in the oxitropium group reported dryness of the mouth. Oxitropium-induced reduction of bronchial secretions should therefore be the largest contributor to the decrease in sputum volume.

Large quantities of airway secretions can interfere with the clearance of inhaled particles, bacteria, and cellular debris from conducting airways, and impair the first line defence mechanism in the lung. ${ }^{16}$ In patients with COPD it has been reported that there is a direct relation between survival and $\mathrm{FEV}_{1}$, whether or not airway hypersecretion is present, ${ }^{17}$ and that the death rates are not significantly related to initial sputum production. ${ }^{18}$ 
However, a 22 year mortality survey of more than 1000 patients with COPD by Annesi and Kauffmann ${ }^{4}$ showed that mortality was associated with both the severity of airway obstruction and chronic sputum production: the increased relative risk related to airway hypersecretion was only $1 \cdot 35$, but it remained significant even when corrected for age, smoking habits, and $\mathrm{FEV}_{1}$. In addition, patients who entered the present study had complained of continuous expectoration of excessive sputum. The reduction of sputum production by oxitropium may benefit the clinical course and quality of life, especially in a working outpatient population.

The mechanisms for the copious sputum production in chronic bronchitis and diffuse panbronchiolitis are uncertain; infectious or inflammatory events and the generation of putative mediators may play an important part. ${ }^{19}$ The reduction of sputum production by oxitropium in our study suggests that the increased cholinergic tone may be involved in the pathogenesis. Stimulation of the parasympathetic nervous system promotes respiratory mucus secretion ${ }^{56}$ and transmucosal electrolyte transport and, hence, water secretion. ${ }^{7}$ The administration of atropine, a tertiary ammonium compound, decreases sputum volume in patients with asthma, chronic bronchitis and bronchiectasis by inhibiting bronchial gland secretion without apparent changes in mucus viscoelastic properties. ${ }^{20}$ However, Pavia and colleagues ${ }^{21}$ showed that the quaternary ammonium compound oxitropium did not alter sputum production or rheology during a four week course of treatment. In agreement with that study, we found that oxitropium had no effect until beyond five weeks, but it significantly decreased sputum volume and increased its percentage solid composition and elasticity thereafter. The increase in percentage solid composition and elasticity suggests less hydration of the sputum or increased mucus glycoprotein secretion, but the latter possibility appears unlikely as calculated values of total solids decreased from $1.54 \mathrm{~g} /$ day on day 0 to $1.27 \mathrm{~g} /$ day after treatment. Inhalation of oxitropium therefore probably inhibits both mucus and water secretion, and the reduction of sputum volume results from decreased water secretion.

Previous studies have shown that oxitropium did not alter mucus transport in pigeons $s^{22}$ nor in patients with chronic bronchitis or asthma after four weeks of treatment. ${ }^{21}$ Shih and associates, ${ }^{23}$ using reconstituted lyophilised mucus, showed that the transport rate of mucus in bullfrogs increased with increasing elastic modulus up to a $G^{\prime}$ value of $10 \mathrm{dyne} / \mathrm{cm}^{2}$, and then gradually decreased with increasing elasticity. Although this finding may not be true in the human airways in vivo, oxitropium may inhibit mucus transport because the $G^{\prime}$ values of the sputum were greater than $10 \mathrm{dyne} / \mathrm{cm}^{2}$ in all patients before the treatment and increased after the study. Inhalation of oxitropium did not alter the sputum microbiology, suggesting that over the treatment period there was no increase in the risk of respiratory tract infection secondary to the changes in the physical properties of the sputum.

In conclusion, regular inhalation of oxitropium for eight weeks in patients with chronic bronchitis or diffuse panbronchiolitis improves airflow limitation but also can decrease sputum production and alter the physical properties of expectorated sputum.

The authors thank Kiyoshi Takeyama and Masayuki Shino for their technical assistance. This work was supported in part by Scientific Research Grant 04670476 from the Ministry of Education, Science, and Culture, Japan.

1 Gross NJ. The influence of anticholinergic agents on treatment for bronchitis and emphysema. $A m$ f Med 1991;91(Suppl 4a): 11S-12S.

2 Peel ET, Anderson G. A dose response study of oxitropium bromide in chronic bronchitis. Thorax 1984;39:453-6.

3 Coe CI, Barnes PJ. Reduction of nocturnal asthma by an inhaled anticholinergic drug. Chest 1986;90:485-8.

4 Annesi I, Kauffmann F. Is respiratory mucus hypersecretion really an innocent disorder? Am Rev Respir Dis 1986;134:688-93.

5 Nadel JA. Neural control of airway submucosal gland secretion. Eur 7 Respir Dis 1983;64(Suppl 128):322-6.

6 Tokuyama K, Kuo H-P, Rohde JAL, Barnes PJ, Rogers DF. Neural control of goblet cell secretion in guinea pig DF. Neural control of goblet cell secretion in
airways. Am $\mathcal{F}$ Physiol 1990:259:L108-L115.

7 Marin MG, Davis B, Nadel JA. Effect of acetylcholine on $\mathrm{Cl}^{-}$and $\mathrm{Na}^{+}$fluxes across dog tracheal epithelium in vitro. Am f Physiol 1976;231:1546-9.

8 Homma H, Yamanaka A, Tanimoto S, Tamura M, Chijimatsu Y, Kira S, et al Diffuse panbronchiolitis: a disease of the transitional zone of the lung. Chest 1983;83:63-9.

9 Sugiyama Y, Kudoh S, Maeda H, Suzaki H, Takaku F. Analysis of HLA antigens in patients with diffuse panbronchiolitis. Am Rev Respir Dis 1990;141:1459-62.

10 The WHO epidemiology of chronic nonspecific respiratory diseases. Bull WHO 1975;52:251-9.

11 Newman SP. Therapeutic aerosols. In: Clarke SW, Pavia $\mathrm{D}$, eds. Aerosol and the lung: clinical and experimental aspects. London: Butterworth, 1984:197-224.

12 Rubin BK, Ramirez O, Zayas JG, Finegan B, King $M$. Collection and analysis of respiratory mucus from subjects without lung disease. Am Rev Respir Dis 1990;141:1040-3.

13 Lutz RJ, Litt M, Chakrin LW. Physicochemical factors in mucus rheology. In: Gabelnick HL, Litt M, eds. Rheology
of biological systems. Springfield, Illinois: Charles C Thomas, 1973;119-24.

14 Johnson NT, Villalón M, Royce FH, Hard R, Verdugo P. Autoregulation of beat frequency in respiratory cells. $\mathrm{Am}$ Rev Respir Dis 1991;144:1091-4.

15 Regelmann WE, Elliott GR, Warwick WJ, Clawson CC. Reduction of sputum Pseudomonas aeruginosa density by antibiotics improves lung function in cystic fibrosis more than do bronchodilators and chest physiotherapy alone. Am Rev Respir Dis 1990;141:914-21.

16 Wanner A. The role of mucus in chronic obstructive pulmonary disease. Chest 1990;97(Suppl):11-5.

17 Anthonisen NR, Wright EC, Hodgkin JE, IPPB trial group. Progress in obstructive pulmonary disease. $\mathrm{Am}$ Rev Respir Dis 1986;133:14-20.

18 Peto R, Speizer FE, Cochrane AL, Moore F, Fletcher CM, Tinker CM, et al. The relevance in adults of air-flow obstruction, but not of mucus hypersecretion, to mortality from chronic lung disease: results from 20 years of prospective observation. Am Rev Respir Dis 1983;128:491-500.

19 Lundgren JD, Shelhamer JH. Pathogenesis of airway mucus hypersecretion. $\mathcal{f}$ Allergy Clin Immunol 1990;85:399-417.

20 Lopez-Vidriero MT, Costello J, Clarke TJH, Das I, Keal EE, Reid L. Effect of atropine on sputum production. Thorax 1975;30:543-7.

21 Pavia D, Lopez-Vidriero MT, Agnew JE, Taylor RG, Eyre-Brook A, Lawton WA, et al. Effect of four-week treatment with oxitropium bromide on lung mucociliary clearance in patients with chronic bronchitis or asthma. Respiration 1989,55:33-43.

22 Miyata T, Matsumoto N, Yuki H, Oda Y, Takahama K, $\mathrm{Kai} H$. Effect of anticholinergic bronchodilators on mucociliary transport and airway secretion. $\mathcal{F} p n \mathcal{F}$ Pharmacol 1989;51:11-5

23 Shih CK, Litt M, Khan MA, Wolf DP. Effect of nondialyzable solids concentration and viscoelasticity on ciliary transport of tracheal mucus. Am Rev Respir Dis 1977;115:989-95. 